\title{
Endogenous Information, Foreign Banks Entry and SMEs Access to Credit in Emerging Economies
}

\author{
Zhaojun Li \\ School of Economics \\ University of Jinan \\ Jinan, China \\ lzj19910608@sina.com
}

\author{
Xuemei Yuan* \\ School of Economics \\ University of Jinan \\ Jinan, China \\ se_yuanxm@ujn.edu.cn
}

\begin{abstract}
The empirical literature is inconclusive regarding the impact of foreign banks entry on SMEs access to credit, while the theoretical literature supports the cherry-picking behavior of foreign banks. Using a two-period theoretical model in which domestic banks' information is endogenous, the analysis fully considers the foreign banks' technological and cost of funds advantage and domestic banks' informational advantage. The paper finds that foreign banks improve access to credit for SMEs, and there exists a negative correlation between the quality of firms and the domestic banks' information. The findings provide theoretical support that emerging economies can further remove foreign banks entry barriers to ease the financing problem of SMEs.
\end{abstract}

Keywords-foreign banks; access to credit; SMEs; emerging economies

\section{INTRODUCTION}

The economic growth of emerging economies slowed to $5.1 \%$ in 2013, although significantly higher than that of advanced economies. Facing the declining potential growth, credit slowdown and capital outflows, economic downturn may last longer (IMF). Emerging economies have a large number of small and medium-sized enterprises (SMEs), which play an important role in promoting economic growth and creating jobs. However, SMEs around the world face financing difficulties. Advanced economies formulate a variety of financial support policies to ease financing difficulties, while banks are the main source of external finance for SMEs in emerging economies because of underdeveloped capital markets. Banks tend to fund the largest and the most informationally transparent firms, ignoring SMEs. Currently, there is a huge credit gap for SMEs in emerging economies. The International Finance Corporation (IFC) latest statistics shows, including high-income OECD countries, the credit gap for formal SMEs is \$ 1.5-1.8 trillion, of which \$0.9-1.1 trillion is from emerging and developing economies.

The presence of foreign banks in emerging economies has significantly increased since the early 1990s. The average share of total assets held by foreign banks in emerging and developing economies increased from $26 \%$ in 1999 to $46 \%$ only 10 years later in 2009 (Cull and Peria, 2013). Hence, the impact of foreign banks entry on credit allocation, especially for SMEs, causes widespread concern among policymakers and economists. A considerable empirical literature finds foreign banks pick the largest and the most transparent firms, and leave smaller and opaque firms to the domestic banks (e.g. Stiglitz, 2000; Satta, 2004; Mian, 2006[1]; Berger et al., 2008; Pennathur and Vishwasrao, 2014). However, several empirical studies find evidence supporting the behavior of foreign banks lending to SMEs (e.g. de la Torre et al., 2010[2]; Beck et al., 2010; Haas et al., 2010 ). For instance, de la Torre et al. (2010) provide evidence from developed and developing countries that foreign and large banks increasingly use special technologies such as credit scoring, which allow them to lend to opaque firms. The empirical evidence regarding the impact of foreign entry on access to credit for SMEs is inconclusive.

Although empirical studies find evidence that foreign banks entry can directly improve access to credit for SMEs, most theoretical studies do not generate such an outcome. Some theoretical studies assume the serious information asymmetry between domestic and foreign banks (Dell' Ariccia and Marquez, 2004; Sengupta, 2007[3]). In the model, domestic banks have perfect information about firms, whereas foreign banks have no information about firms and no chance to obtain information. Hence, domestic banks have an informational advantage, but foreign banks have a cost of funds advantage. Under these assumptions, Sengupta (2007) finds that foreign banks tend to lend more to large firms thereby neglecting small and medium-sized enterprises, and this observed bias is stronger in emerging markets.

Relaxing the serious information asymmetry assumption, Detragiache et al. (2008)[4] propose a model with the assumption that domestic and foreign banks both have to invest in costly screening technologies to acquire information about firms. In the model, domestic banks have an informational advantage on screening opaque firms because of acquiring soft information, whereas foreign banks have a technological advantage on screening transparent firms because of acquiring hard information. Boustanifar (2014)[5] assumes domestic banks have an informational advantage on screening opaque firms and foreign banks have a cost of fund advantage on lending to transparent firms, which is similar to Gormley (2014)[6].

The above empirical literature demonstrates how the difference of advantage between the domestic and foreign banks affects the overall distribution of credit. However, the most theoretical literature supports that foreign banks ignore SMEs, but only lend to the largest and the most informationally transparent firms. This paper formulates a two-period 
theoretical model in which domestic banks' information is endogenous, and finds the conclusions by fully considering the foreign banks' technological and cost of funds advantage and domestic banks' informational advantage.

\section{SETUP OF THE MODEL}

\section{A. Agents}

There are two types of agents: firms and banks. The agents are risk-neutral and the firms are limited liability. All firms have zero wealth and must find a bank to obtain financing. Banks are perfectly competitive. They have a perfectly elastic supply of funds. Firms are either opaque or transparent. All transparent firms are large and profitable, denoted by L, while all opaque firms are small and medium-sized, denoted by profitable S and non-profitable B (bad firms). Hence, in general there are three types of firms, whose proportion are given by $\lambda_{L}, \lambda_{S}$ and $\lambda_{B}$ so that $\lambda_{L}+\lambda_{S}+\lambda_{B}=1$. For simplicity, this paper assumes that $\lambda_{S}+\lambda_{B}=\lambda$, where $\lambda_{\text {is constant and what }}$ changes is the proportion of these two groups. Each firm has access to a project that requires an initial investment of $I=1$. If the project is implemented, firms of types $\mathrm{L}$ and $\mathrm{S}$ return $R \geq 1$ with probability 1 , while firms of type $\mathrm{B}$ pay off $\mathrm{R}$ with probability $\mathrm{p}$. The latter have a negative expected return such that $p R<1$. However, the limited liability makes it an attractive "gamble", so if firms of type B receive financing they invest.

\section{B. Screening costs}

Firm's type information is private. Banks can not identify firms unless investing in costly screening technologies. Domestic banks' information about firms at the time of foreign banks entry is endogenous and it depends on the previous screening of domestic banks. In other words, domestic banks can costlessly distinguish firms that have been already screened. Furthermore, foreign banks can not free ride and obtain the information acquired by domestic banks. Banks have two kinds of screening technologies: L-technology to distinguish firms of type $\mathrm{L}$ and more expensive S-technology to distinguish firms of type S. Domestic banks have access to funds at a constant interest rate which is normalized to 1 , whereas the foreign banks' cost of funds $v$ is lower because of the cost advantage, i.e. $v<1$. Domestic banks screen firms of type $\mathrm{L}$ and $\mathrm{S}$ at the cost $C_{L}$ and $C_{S}$. Distinguishing opaque firms is more costly than distinguishing transparent firms such that $c_{S}>C_{L}$. Foreign banks, relative to domestic banks, have informational disadvantage in screening opaque firms. This paper assumes additionally that foreign banks, relative to domestic banks, have technological advantage in screening transparent firms, which is unlike Boustanifar (2014). Hence, foreign banks bear a lower cost of distinguishing firms of type L but a higher cost of distinguishing firms of type $\mathrm{S}$ than domestic banks, denoted by $\theta c_{L}$ and $c_{S} / \theta$, where $0<\theta<1$. Furthermore, $\theta$ is interpreted as the institutional quality of the host country: the larger the $\theta$, the higher the quality, so the higher the screening cost foreign banks pay for distinguishing firms of type $\mathrm{L}$ and the lower the screening cost foreign banks pay for distinguishing firms of type S.

\section{Screening contracts}

There is a two period model. Domestic banks are the only lenders in the first period, while domestic banks compete with foreign banks in the second period. Banks offer a menu of contract consisting of one or more interest rate/screening strategy combinations: a pooling rate to all firms without any screening, another interest rate with screening of transparent firms, and a third interest rate with screening of opaque firms. Hence, there are three types of contracts: a pooling contract that all firms are pooled, a semi-pooling contract that firms of types $\mathrm{T}$ are screened and the others are pooled, and a separating contract that both types are screened. Firms choose one of the offered contracts or choose no contract.

\section{EQUILIBRIUM OF ONLY DOMESTIC BANKS}

In the first period, the game might have four different equilibrium outcomes. In a pooling equilibrium, all firms are pooled and funded with the same interest rate. In a semipooling equilibrium, firms of types $\mathrm{T}$ are screened, while firms of types S and B are pooled. In a separating equilibrium, firms of types L and S are screened and funded, while firms of types B can not receive any credit. Finally, in a credit constrained equilibrium, only firms of types L are screened and funded, while firms of types S and B can not receive any credit.

If the proportion of bad firms is very low, all firms will choose a pooling contract. The cost of adverse selection is lower than the screening cost. For domestic banks to break even, they must charge a pooling interest rate $r_{p}^{D}$ such that:

$\left[p \lambda_{B}+\lambda_{S}+\lambda_{L}\right] r_{p}^{D}=1 \Rightarrow r_{p}^{D}=\frac{1}{p \lambda_{B}+\lambda_{S}+\lambda_{L}}=\frac{1}{1-(1-p) \lambda_{B}}$ Obviously, the pooling interest rate depends on the proportion of bad firms and rises as the proportion increases. For all firms to accept the pooling contract, there do not exist a more attractive interest rate on offer. Hence, the pooling interest rate must be less than the interest rate $r_{L}^{D}$ that domestic banks charge to break even when distinguishing firms of type L, i.e. $r_{L}^{D}=1+c_{L}>r_{p}^{D}$

should not exceed the

participation constraint of all firms, i.e. $R>r_{p}^{D}$. Otherwise, no profitable firm would accept a pooling contract, as it generates

negative profits. In this case, the equilibrium outcome is a pooling one.

If the proportion of bad firms is moderately high, the pooling interest rate will exceed the interest rate of screening transparent firms. Hence, firms of type $\mathrm{L}$ will choose a screening contract and sort themselves out with a interest rate $r_{L}^{D}$. However, opaque firms face two choices: a screening contract or a pooling contract. Since the proportion of bad firms is not too high, the interest rate of screening profitable opaque firms exceeds the interest rate of pooling opaque firms. Opaque firms choose a pooling contract. In other words, firms 
of types $\mathrm{S}$ and $\mathrm{B}$ are pooled together and funded if $r_{S}^{D}=1+c_{S}>r_{s p}^{D}$, where $r_{s p}^{D}$ is the interest rate that domestic banks charge to break even when firms of types $\mathrm{S}$ and $\mathrm{B}$ are pooled together, i.e. :

$$
\left[\frac{\lambda_{S}}{\lambda_{B}+\lambda_{S}}+\frac{p \lambda_{B}}{\lambda_{B}+\lambda_{S}}\right] r_{s p}^{D}=1 \Rightarrow r_{s p}^{D}=\frac{\lambda}{\lambda-(1-p) \lambda_{B}}
$$

Note that $r_{p}^{D}$ is always lower than $r_{s p}^{D}$, because domestic banks face a worse pool of firms when firms of type $L$ drop out of the pool. Meanwhile, the participation constraint of all firms need to be satisfied so that $r_{s p}^{D}$ is less than the return on projects, i.e. $R>r_{s p}^{D}$. In this case, the equilibrium outcome is a semi-pooling one.

If the proportion of bad firms is too high, the interest rate of pooling opaque firms will exceed the interest rate of screening profitable opaque firms. Opaque firms choose a screening contract. Hence, both firms of type L and S are identified and funded. In addition, the return on projects should exceed the interest rate of screening profitable opaque firms to satisfy the participation constraint of profitable firms, i.e. $R>r_{S}^{D}$. In this case, the equilibrium outcome is a separating one.

However, with the high proportion of bad firms, last possible equilibrium outcome will happen if the return on projects is not sufficient to exceed the interest rate of screening profitable opaque firms or the interest rate of pooling opaque firms, i.e. $R<\min \left\{r_{s}^{D}, r_{s p}^{D}\right\}$. In this case, the equilibrium outcome is a credit constrained one, where only firms of type $\mathrm{L}$ receive credit.

The possible four different equilibrium outcomes only with domestic banks are as follow:

Lemma 1. If $R>r_{p}^{D}$ and $r_{L}^{D}>r_{p}^{D}$, the equilibrium outcome is a pooling. All firms are funded and no screening costs are paid.

Lemma 2. If $r_{L}^{D}<r_{p}^{D}, r_{S}^{D}>r_{s p}^{D}$ and $r_{s p}^{D}<R$, the equilibrium is a semi-pooling. Firms of type $L$ are screened and funded at the interest rate $r_{L}^{D}$, while firms of type $S$ and $B$ are pooled together and funded at the interest rate ${ }^{r_{s p}^{D}}$.

Lemma 3. If $r_{L}^{D}<r_{p}^{D}, r_{S}^{D}<r_{s p}^{D}$ and $r_{S}^{D}<R$, the equilibrium is a separating. Firms of type $L$ and $S$ are screened and funded at the interest rate $r_{L}^{D}$ and $r_{S}^{D}$, respectively. Firms of type $B$ are not funded.

Lemma 4. If $r_{L}^{D}<r_{p}^{D}, R>r_{L}^{D}$ and $R<\min \left\{r_{s}^{D}, r_{s p}^{D}\right\}$, the equilibrium is a credit constrained. Only firms of type $\mathrm{L}$ are screened and funded, while firms of type S and B are not funded.

\section{EQUILIBRIUM OF FOREIGN BANKS ENTRY}

Through the above analysis, it is found that domestic banks will have more firm's type information by paying screening costs as the proportion of bad firms increases. In other words, there exists a negative correlation between the quality of firms in a sector and the domestic banks' information about firms. Four different equilibrium outcomes in the first period imply various levels of information asymmetry between domestic and foreign banks in the second period. In the second period, domestic and foreign banks compete with each other in offering credit to firms. Since domestic banks' information about firm is endogenous, they can costlessly distinguish firms that have been already screened. Next, this paper will discuss what happens for firms' access to credit, especially for SMEs, after foreign banks enter four different equilibrium outcomes in the first period.

Obviously, after foreign banks enter a pooling equilibrium, domestic banks can not distinguish any firms costlessly because no firm has been already screened in the first period. Since the cost of funds for foreign banks is lower than that of domestic banks, foreign banks relative to domestic banks can offer a lower pooling interest rate for all firms, i.e. $r_{p}^{F}=v /\left[1-(1-p) \lambda_{B}\right]<1 /\left[1-(1-p) \lambda_{B}\right]=r_{p}^{D}$. In this case, foreign banks will attract all firms and push domestic banks completely out of the credit market. Hence, a pooling equilibrium outcome realizes after foreign banks entry in a pooling market. However, the statistics shows that the presence of both domestic and foreign banks is by far the most common pattern following foreign banks entry, hence there is no possibility that only foreign banks exist in the whole market. To be realistic, this paper only focuses on cases with the presence of both domestic and foreign banks, i.e. cases that foreign banks enter other three equilibrium outcomes in the first period.

\section{A. Entering a semi-pooling equilibrium}

After foreign banks enter a semi-pooling equilibrium, domestic banks can screen firms of type L costlessly and offer the interest rate $r_{L}^{D}=1$ to them because of the previous screening. Since the cost of funds for foreign banks is lower than that for domestic banks, foreign banks relative to domestic banks offer a lower interest rate of pooling opaque firms, i.e. $r_{s p}^{F}=\lambda v /\left[\lambda-(1-p) \lambda_{b}\right]<\lambda /\left[\lambda-(1-p) \lambda_{b}\right]=r_{s p}^{D}$

Meanwhile, a semi-pooling equilibrium in the first period implies that the proportion of bad firms is not too high, so the interest rate of screening profitable opaque firms exceeds the interest rate of pooling opaque firms offered by foreign banks, i.e. $r_{S}^{F}=v+c_{O} / \theta>r_{s p}^{F}$, so that $\theta<c_{s} /\left(r_{s p}^{F}-v\right)$. Hence, firms of type $S$ and $B$ are pooled and funded by foreign bank. In addition, the foreign banks' cost advantage should not be too high to force domestic banks out of the whole market. In other words, the interest rate offered to firms of type L by domestic banks must be less than that by foreign banks, i.e., $r_{L}^{D}=1<r_{L}^{F}=v+\theta_{T}$, so that $\theta>(1-v) / c_{T}$. In this case, firms of type $L$ are funded by domestic banks. Hence, a semi- 
pooling equilibrium outcome realizes after foreign banks entry in a semi-pooling market.

Proposition 1. After foreign banks entry in a semi-pooling market, if $(1-v) / c_{L}<\theta<c_{S} /\left(r_{s p}^{F}-v\right)$, the equilibrium outcome is a semi-pooling. Transparent and large firms are funded with the interest rate $r_{L}^{D}=1$ by domestic banks, whereas the SMEs are pooled and funded with the interest rate $r_{s p}^{F}=\lambda v /\left[\lambda-(1-p) \lambda_{B}\right]$ by foreign banks. SMEs enjoy a lower rate because of the foreign banks entry.

\section{B. Entering a separating equilibrium}

After foreign banks enter a separating equilibrium, domestic banks can distinguish firms of type L and S costlessly, offering the interest rate $r_{L}^{D}=1$ and $r_{S}^{D}=1$, respectively. Considering the presence of both domestic and foreign banks in the market, the interest rate of distinguishing firms of type $\mathrm{L}$ and $\mathrm{S}$ offered by foreign banks must satisfy that $r_{L}^{F}=v+\theta c_{T}<r_{L}^{D}=1$ and $r_{S}^{F}=v+\theta c_{S}>r_{S}^{D}=1$, i.e. $1-c_{S} / \theta<v<1-\theta c_{L}$. For $r_{L}^{F}<r_{L}^{D}$, foreign banks can lend to firms of type L. Meanwhile, domestic banks will fund firms of type $\mathrm{S}$ because of $r_{S}^{F}>r_{S}^{D}$. However, firms of type B do not receive any credit. Hence, a separating equilibrium outcome realizes after foreign banks entry in a separating market.

Proposition 2. After foreign banks entry in a separating market, if $(1-v) / c_{L}<\theta<c_{S} /\left(r_{s p}^{F}-v\right)$, the equilibrium outcome is a separating. Transparent and large firms are funded with the interest rate $r_{L}^{F}=v+\theta c_{T}$ by foreign banks, whereas the profitable SMEs are funded with the interest rate $r_{S}^{D}=1$ by domestic banks. Large firms enjoy a lower rate because of foreign banks entry.

\section{Entering a credit constrained equilibrium}

After foreign banks enter a credit constrained equilibrium, domestic banks can only distinguish firms of type L costlessly and offer the interest rate $r_{L}^{D}=1$ to them because of the previous screening. Meanwhile, a credit constrained equilibrium in the first period implies that domestic banks can not fund the opaque firms because of the high screening cost and adverse selection. Hence, transparent firms must be funded by domestic banks considering the presence of both domestic and foreign banks in the market. In other words, foreign banks relative to domestic banks must offer the higher interest rate to firms of type L, so $r_{L}^{F}=v+\theta c_{L}>r_{L}^{D}=1$, where $v>1-\theta c_{L}$. For a relatively high $\theta$, foreign banks have a comparative advantage in screening opaque firms. Therefore, firms of type $\mathrm{S}$ are screened and funded by foreign banks. The interest rate of screening firms of type $\mathrm{S}$ offered by foreign banks must be less than that by domestic banks, i.e. $r_{S}^{F}=v+c_{S} / \theta<1+c_{S}=r_{S}^{D}$, where $v<1-(1 / \theta-1) c_{S}$. Obviously, in this case, $1-\theta c_{L}<v<1-[1 / \theta-1] c_{S}$

where $\theta>\max \left\{(1-v) / c_{L}, c_{S} /\left(1+c_{S}-v\right)\right\}$. Hence, for all $R \geq v+c_{S} / \theta$, a separating equilibrium outcome realizes after foreign banks entry in a credit constrained market.

Proposition 3. After foreign banks entry in a credit constrained market, for all $R \geq v+c_{S} / \theta$, if $\theta>\max \left\{(1-v) / c_{L}, c_{S} /\left(1+c_{S}-v\right)\right\} \quad, \quad$ the equilibrium outcome is a separating. Transparent and large firms are funded with the interest rate $r_{L}^{D}=1$ by domestic banks, whereas the profitable SMEs are funded with the interest rate $r_{S}^{F}=v+c_{S} / \theta$ by foreign banks. Profitable SMEs enjoy increased access to credit because of foreign banks entry.

\section{CONCLUSIONS}

Using a two-period theoretical model in which domestic banks' information is endogenous, this paper finds four main conclusions as follow: First, when the proportion of bad firms is moderately high in the market, foreign banks lend to all SMEs at a cheaper interest rate and domestic banks fund large firms. Second, when the proportion of bad firms is too high in the market, foreign banks only lend to large firms, which is referred as "cherry picking" or "cream-skimming" behavior. Profitable SMEs are funded by domestic banks, while bad firms do not receive any credit. Third, when the proportion of bad firms is too high and the screening cost of SMEs is too large, foreign banks only lend to profitable SMEs if the legal environment of the host country is relatively rich. In this case, large firms are funded by domestic banks, while bad firms do not receive any credit. Last, there is a negative correlation between the quality of firms in a sector and the domestic banks' information about firms. Obviously, although preferring large firms is a possible outcome of foreign banks entry, this is not always the case. If the legal environment of the host country is relatively rich, foreign banks will fund SMEs in emerging economies. Hence, the policymakers should be encouraged to open financial service market further to benefit SMEs.

\section{ACKNOWLEDGMENT}

This work was supported by The National Social Science Funds project "The research on foreign direct investment in banking sector of emerging market economies” (Grant No. 11BGJ009) and Shandong Provincial Natural Science Foundation(Grant No. ZR2012GL01).

\section{REFERENCES}

[1] Mian A. "Distance constraints: the limits of foreign lending in poor economies,” Journal of Finance 2006, vol. 61, pp. 1465-1505.

[2] de la Torre A, Pera, M S M, Schmukler S L. "Bank involvement with SMEs: Beyond relationship lending," Journal of Banking \& Finance, 2010, vol. 34, pp. 2280-2293.

[3] Sengupta R. "Foreign entry and bank competition,” Journal of Financial Economics, 2007, vol. 84, pp. 502-528.

[4] Detragiache E, Tressel T, Gupta P. "Foreign banks in poor countries: theory and evidence,” Journal of Finance, 2008, vol. 63, pp. 2123-2160. 
[5] Boustanifar H. "Information acquisition, foreign bank entry, and credit allocation,”The Quarterly Review of Economics and Finance, 2014, vol. 54, pp.324-336.
[6] Gormley T A. “Costly information, foreign entry, and credit access," Journal of Economic Theory, 2014, vol. 154, pp. 633-667. 